\title{
The Expression Profiles of Angio-miRs in Glioblastomas Invasion Inhibited by Ruxolitinib
}

\author{
Ruksolitinib ile Engellenen Glioblastoma Invazyonunda AnjiyomiR'Ierin Ekspresyon Profili
}

\author{
(1) Emre DELEN ${ }^{1}$, (1) Oğuzhan DOĞANLAR ${ }^{2}$ \\ ${ }^{1}$ Trakya University Faculty of Medicine, Department of Neurosurgery, Edirne, Turkey \\ 2Trakya University Faculty of Medicine, Department of Medical Biology, Edirne, Turkey
}

\begin{abstract}
Aim: MicroRNAs (miR) have an essential role on the regulated gene expression in the human genome. In recent years, a specific miR group was called to angio-miRs due to their role in the angiogenesis, and recent study showed that they involved in the pathogenesis of gliomas. In this study, we investigated the changes in the expression profiles of angio-miRs in glioblastoma cells and identified relationship between these genes and invasion and tumor growth.
\end{abstract}

Materials and Methods: In this study, glioblastoma tumor spheroids were obtained using the human glioblastoma cell line U-87 MG. 50 nM, $100 \mathrm{nM}$ and $200 \mathrm{nM}$ ruxolitinib were applied to tumor spheroids for 48 hours by using Matrigell method. Tumor volume and invasion formation relative $\%$ tumor growth and relative $\%$ invasion area were measured in glioblastoma tumor spheroids after 48 hours of treatment. At the same time, quantitative real-time polymerase chain reaction (qRT-PZR) analysis was performed and miR expression profiles were determined. The most important (importance features) miRNAs selected along with the heatmap and volcano plot analyzes were used to display the pattern of the differentially expressed miRs using normalized miR expression profiles.

Results: When the effect of $50 \mathrm{nM}, 100 \mathrm{nM}$ and $200 \mathrm{nM}$ ruxolitinib administration to tumor spheroids on tumor volume and invasion was evaluated, a significant difference was found at each dose applied. However, at the dose of $200 \mathrm{nM}$ ruxolitinib, it was observed that the inhibitory effect of tumor invasion was the highest. When miR expression profiles obtained by qRT-PZR test with $200 \mathrm{nM}$ ruxolitinib adminisration were evaluated, it was determined that the expression profiles of $10 \mathrm{miRs}$ increased and the expression profiles of 4 miRs decreased.

Conclusion: In conclusion, angio-miR expression profiles are important because they enable us to better understand the prognostic process of gliomas. Because of their multiple silencing properties, they may contribute to the clinic with further studies in terms of their use as new therapeutic targets and prognostic biomarkers for glioblastoma.

Keywords: miR, glioblastoma, angiogenesis, invasion

ÖZ

Amaç: MikroRNA'lar (miR), insan genomunda gen ifadesinin düzenlenmesinde önemli rolü olan düzenleyicilerdir. Son yıllarda anjiyogenezde rol oynayan spesifik bir miR grubu tanımlanmış (anjiyo-miR) ve bazı anjiyo-miR'lerin gliomalarda etkin rol oynadıkları ortaya konmuştur. Bu çalışmada, glioblastoma hücrelerindeki anjiyo-miR'lerin ifade değerlerindeki değişiklikleri ve bu değişikliklerin invazyon ve tümör büyümesi ile ilişkisini araştırdık.

Gereç ve Yöntem: Bu çalışmada, insan glioblastoma hücre hattı U-87 MG kullanılarak glioblastoma tümör sferoidleri elde edildi. Matrigel yöntemi ile tümör sferoidlerine 48 saat süresince 50 nM, 100 nM and $200 \mathrm{nM}$ ruksolitinib uygulandı. Kırk sekiz saat tedaviden sonra glioblastoma tümör sferoidlerinde tümör hacmi ve invazyon oluşumu relatif yüzde tümör gelişimi ve relatif yüzde invazyon alanı ölçüldü. Aynı zamanda, niceliksel gerçek zamanlı polimeraz zincir reaksiyonu (qRT-PZR) analizi yapıldı ve miR ifade değerleri belirlendi. Farklı şekillerde ifade edilen miRNA'ların modelini görüntülemek için normalize edilen miRNA ifade değerleri kullanılarak heatmap ve volcano plot analizleri ile seçilen en önemli (importance features) miRNA'lar gösterildi.

Address for Correspondence: Emre DELEN MD, Trakya University Faculty of Medicine, Department of Neurosurgery, Edirne, Turkey Phone: +90 5306144646 E-mail: emredelen1979@yahoo.com ORCID ID: orcid.org/0000-0001-5573-9492

Received: 07.09.2021 Accepted: 13.10.2021

๑Copyright 2022 by the Tekirdağ Namık Kemal University Faculty of Medicine / Namık Kemal Medical Journal published by Galenos Publishing House. 
Bulgular: Tümör sferoidlerine 50 nM, 100 nM ve 200 nM ruksolitinib uygulamasının tümör hacmi ve invazyon üzerine etkisi değerlendirildiğinde, uygulanan her dozda anlamlı fark saptandı. Ancak 200 nM ruksolitinib dozunda tümör yayılımını engelleyici etkisinin en yüksek olduğu gözlendi. 200 nM ruksolitinib uygulaması ile qRT-PZR testi ile elde edilen miR ifade değerleri incelendiğinde 10 miR'nin ifade değerlerinin arttığı, 4 tanesinin ifade değerlerinin ise azaldığı belirlendi.

Sonuç: Sonuç olarak anjiyo-miR ifade değerleri gliomaların prognostik sürecini daha iyi anlamamızı sağlayabilmeleri açısından önemlidirler. Çoklu susturma özellikleri sayesinde glioblastomalar için yeni terapötik hedefler ve prognostik biyobelirteçler olarak kullanılabilmesi açısından ileri çalışmalarla kliniğe katkı sağlayabilirler.

Anahtar Kelimeler: miR, glioblastoma, anjiyogenez, invazyon

\section{INTRODUCTION}

MicroRNAs (miR) are small, single-stranded RNA sequences of 21-25 nucleotides found in the human body. These nonprotein-coding small RNA sequences play a role in physiological and pathological processes by inhibiting gene expression in the post-transcriptional modification step of protein synthesis'. These pathological processes include many types of cancer, including glioblastomas ${ }^{2}$. The close relationship of miRs with these pathologies has led to their being proposed as new therapeutic agents ${ }^{3}$. Recent studies reveal that these small RNAs can be used not only in the treatment phase, but also as a biomarker with varying expression values ${ }^{4}$. As a result, in recent years, miRs have become one of the most frequently studied subjects in laboratory and clinical studies, especially for incurable cancer types ${ }^{1-4}$.

Glioblastomas are among the brain cancers originating from glial cells, growing fast and still fatal with its aggressive nature despite the developing technological opportunities. Although more than 100 subtypes have been defined with their heterogeneous molecular features, the common feature of all of them is high angiogenetic and invasion capacity ${ }^{5,6}$. Glioblastoma cells invade the surrounding healthy brain tissue and spread by sequential angiogenesis. This aggressive spread is thought to be the main difficulty in the treatment of glioblastomas ${ }^{7}$. From this point of view, targeting cytokines and associated signaling pathways involved in this high angiogenetic process seems to be a rational way to treat the disease. However, phase-2 and phase- 3 studies of these treatment interventions have been conducted, and although some positive results have been obtained, a treatment protocol that has been included in routine treatment has not been determined yet ${ }^{8}$. For this, a better understanding of the complex molecular mechanism underlying the high angiogenic and invasive characteristics of gliomas is needed.

In recent years, many miRs, called angio-miRs, closely related to tumor angiogenesis have been identified in the field of cancer biology. Among them, angio-miRs such as miR_7, miR_296, miR_15b and miR_93 have been reported to play a role in glioblastomas. In our laboratory, it was previously reported that ruxolitinib effectively inhibited the invasion of gliomas $^{10}$. In another study, a close relationship of this effect with miR_17 and miR_20a was demonstrated ${ }^{11}$. In this study, the relationship between inhibited invasion characteristics and expression values of 34 angio-miRs in glioblastoma threedimensional tumor clusters was investigated, again using ruxolitinib.

\section{MATERIALS AND METHODS}

\section{Supply of Ruxolitinib and Preparation of Cell Line}

Ruxolitinib (CAS 941678-49-5) was purchased from Santa Cruz Biotechnology (Santa Cruz, CA, USA), and human glioblastoma cell line U-87 MG (ATCC ${ }^{\circledR}$ HTB-14") from American Type Culture Collection; (Manassas, VA, USA). During the study, cells were grown by using Eagle's Minimum Essential Medium (EMEM; catalog no. 30-2003) which was supplemented with 10\% fetal bovine serum (Gibco Life Technologies, Grand Island, NY, USA), $1 \mathrm{mM}$ glutamine, and 1\% (final concentration) penicillin/ streptomycin (Invitrogen, Carlsbad, CA, USA) and kept in a humidified incubator at $37{ }^{\circ} \mathrm{C}$ and $5 \% \mathrm{CO}_{2}$ throughout the entire study.

\section{Construction of Glioblastoma Tumor Clusters and Matrigel Invasion Assay Protocol}

Tumor clusters were created using the hanging drop method, with minor modifications ${ }^{10,11}$. Single-cell suspensions were obtained from trypsinized monolayer cell cultures and diluted to the desired cell density using complete EMEM medium with the addition of $0.5 \%$ methyl cellulose. $20 \mu \mathrm{L}$ of cell suspension was pipetted to the inner surface of the top cover of nonadhesive, sterile polystyrene Petri dishes as 40 drops (final concentration of 750-1.000 cells per drop). The upper lids of the Petri dishes with the tumor droplets were inverted and $2 \mathrm{~mL}$ of phosphate-buffered saline was placed in the lower dish. After the cells were incubated for 72 hours, tumor cluster formation was observed using the ZEISS Axio Vert.A1 (Oberkochen, Germany) invert microscope. All tumor spheres were collected in $15 \mathrm{~mL}$ Falcon tubes and fresh tumor spheres of the same age were used in all experiments.

Twenty-four well plates were used for the Matrigel invasion assay. The plates were covered with an extracellular matrix and the excess of this matrix was removed to form a thin layer. Then, $40 \mu \mathrm{L}$ of tumor clusters collected from the 
previous section were taken and mixed with $100 \mu \mathrm{L}$ of matrigel matrix (Corning, Corning, NY, USA) and $100 \mu \mathrm{L}$ of collagen type I (Sigma Aldrich) in pre-chilled Eppendorf tubes. $40 \mu \mathrm{L}$ (3-5 tumor clusters) of this mixture was put in each well. Afterwards, the plate was left in the incubator for 24 hours, then $1 \mathrm{~mL}$ of cell culture medium was added to each well. After 24 hours, tumor clusters were treated with vehicle or 50, 100, or 200 nM ruxolitinib for 48 hours. Five replicates were made for each process. After 48 hours of treatment, cell invasion was recorded for 48 hours using an inverted phase contrast light microscope at 20X magnification (ZEISS Axio Vert.A1) equipped with a digital camera. Tumor volume and tumor invasion were calculated according to our previous studies $^{10,11}$.

\section{miR Isolation and Quantitative Real Time-polymerase Chain Reaction (RT-qPCR) Analyses}

A group of miRNAs called angio-miRNAs (angio-miRs) is well defined in terms of target genes and expression profile and has been shown to play an important role in glioblastoma multiforme (GBM) pathogenesis. Whole genome-wide microarray studies have revealed that more than 50 miRs are involved in hypoxia-related pro- or anti-angiogenesis signaling ${ }^{12-15}$. In our study, 34 angio-miRs determined in this group were used. Isolation of miRs from tumor spheres 48 hours after the administration of ruxolitinib was performed using the mirVana ${ }^{\mathrm{TM}}$ miR Isolation Kit with phenol according to the kit protocol. cDNAs were synthesized using a TaqMan ${ }^{\mathrm{TM}}$ Advanced miR cDNA Synthesis Kit according to kit protocols. Quantitative real-time polymerase chain reaction (qRT-PCR) analysis was performed on a Quant studio 5 real time PCR (life technologies) using FastStart TaqMan ${ }^{\circledR}$ Probe Master (life technologies). The TaqMan probes and miR sequences used are given in Table 1. miR expression values were calculated by the $2^{-\Delta \Delta C t}$ method, and RNU6B (Assay ID: 001093) was used as correction factor and endogenous control ${ }^{16}$.

\section{Statistical Analysis}

The differences in the invasion rate and tumor volume between the control and experimental groups and the relative fold change in miR expression were compared with one-way analysis of variance and Tukey HSD test. Pearson correlation coefficient method was used for correlation analysis. Statistical analyses were performed using Statistical Package for the Social Sciences 20 software with a significance level of $p<0.05$. Heat map analysis, unsupervised hierarchical clustering analysis, volkano plot and feature importance analysis were performed using MetaboAnalyst 4.0 software to identify potential biomarkers/important miRs in three-dimensional tumor clusters with and without ruxolitinib.

\section{RESULTS}

In the study, 50, 100 and $200 \mathrm{nM}$ doses of ruxolitinib were applied to glioblastoma tumor clusters and their effects were evaluated after 48 hours. Although a statistically significant effect was observed at each applied dose, it was observed that the effect reached the highest level at the $200 \mathrm{nM}$ dose and this effect was consistent with our previous studies (Figure 1) ${ }^{10,11}$. Therefore, the relationship between miR expression values obtained by qRT-PCR test and this effect dose was analyzed and it was determined that the expressions of 10 miRs increased significantly, and 4 of them decreased significantly (Table 2). The heatmap showed that $200 \mathrm{nM}$ ruxolitinib administration had the highest effect on miR expressions compared to the control group (Figure 2). In the next step, in order to determine the miRs directly related to ruxolitinib, first volcano plot and then OPLS-discriminant analysis were performed and the most important features were determined here. Nine miRs, which were found to be significantly correlated with ruxolitinib applications, which gave similar statistically significant results in both analyses, are summarized in Table 3. Correlation analyses of these identified miRs were then performed with
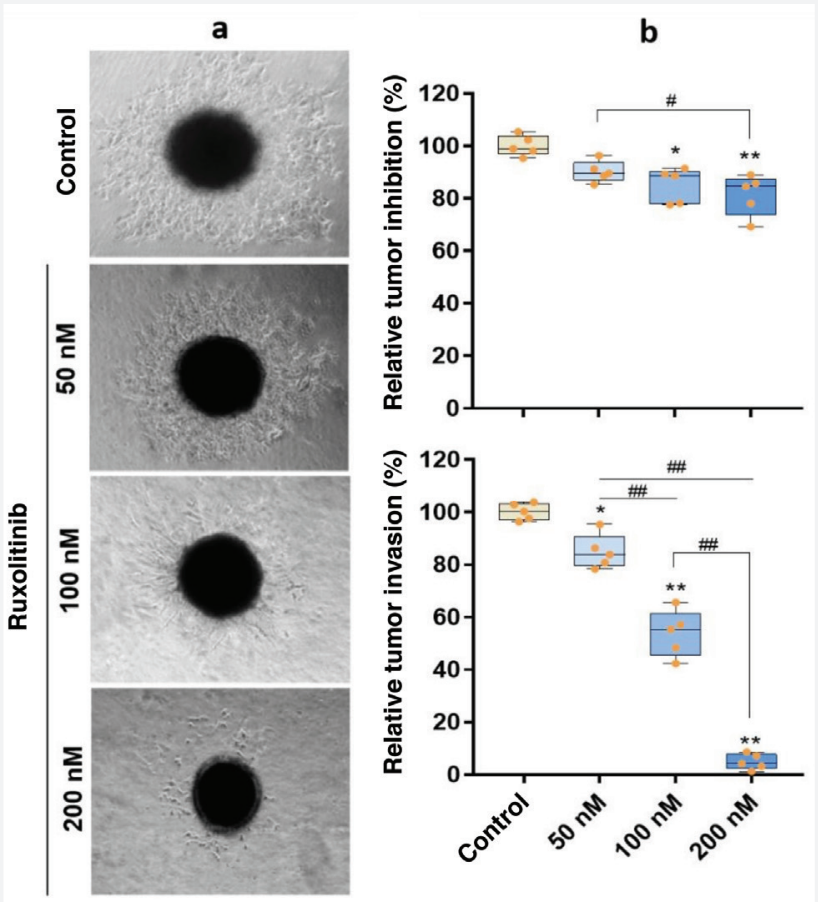

Figure 1. A) GBM tumor spheroids and invasion formation determined by Matrigel method, b) Relative \% tumor growth and relative $\%$ invasion area in GBM tumor spheres treated with $50 \mathrm{nM}, 100 \mathrm{nM}$ and $200 \mathrm{nM}$ ruxolitinib or vehicle for 48 hours. Bars mean $\pm S E, n=5$, ${ }^{*}$ statistically different compared to control, "statistically different from other groups, oneway ANOVA, Tukey HSD test, $\mathrm{p} \leq 0.05 ;{ }^{* *},{ }^{\# \#} \mathrm{p} \leq 0.01$

GBM: Glioblastoma multiforme 
tumor volumes and invasion rates, and as a result, 5 miRs [miR_15b(r:-0,659/-0,861]; miR_19a_3p(r:-0,713/-0,455); miR_31_3p(r:-0,461/-0,533); miR_155_3p(r:-0,572/-0,625); miR_200b_5p(r:-0,673/-0,957) among 9 miRs, which showed a statistically significant correlation with both tumor invasion and tumor growth, were detected (Figure 3).

\section{DISCUSSION}

In recent years, with the developments in the field of molecular biology, large volumes of data have begun to be examined, thus it has been demonstrated that miRs are closely related to tumor invasion, and various cancer-specific miRs have been defined $^{17-19}$. It is suggested that inhibition of miRs specific to this cancer type is a new target that can be used in the treatment of cancer ${ }^{1}$. In the present study, miRs associated with U87 glioblastoma invasion, which we blocked using ruxolitinib that we previously used in our laboratory, were determined. In this context, it was determined that there was an increase in 10 miR expression values and a decrease in 4 miR expression values in GBM tumor spheres treated with ruxolitinib for 48 hours. It was determined that miR_15b, miR_18a_5p, miR_19a_3p, miR_21_5p, miR_27a_5p, miR_31_3p, miR_132_5p, miR_155_3p and miR_200b_5p had a statistically significant effect on the invasion and tumorigenesis of U87 GBM spheres.

miR_15b is a miR localized in the $3^{\text {rd }}$ chromosome of the human genome and has been frequently studied in cancer studies

\section{Table 1. Names of mikro-RNAs, Taq-Man probe ID and mature miRNA sequences}

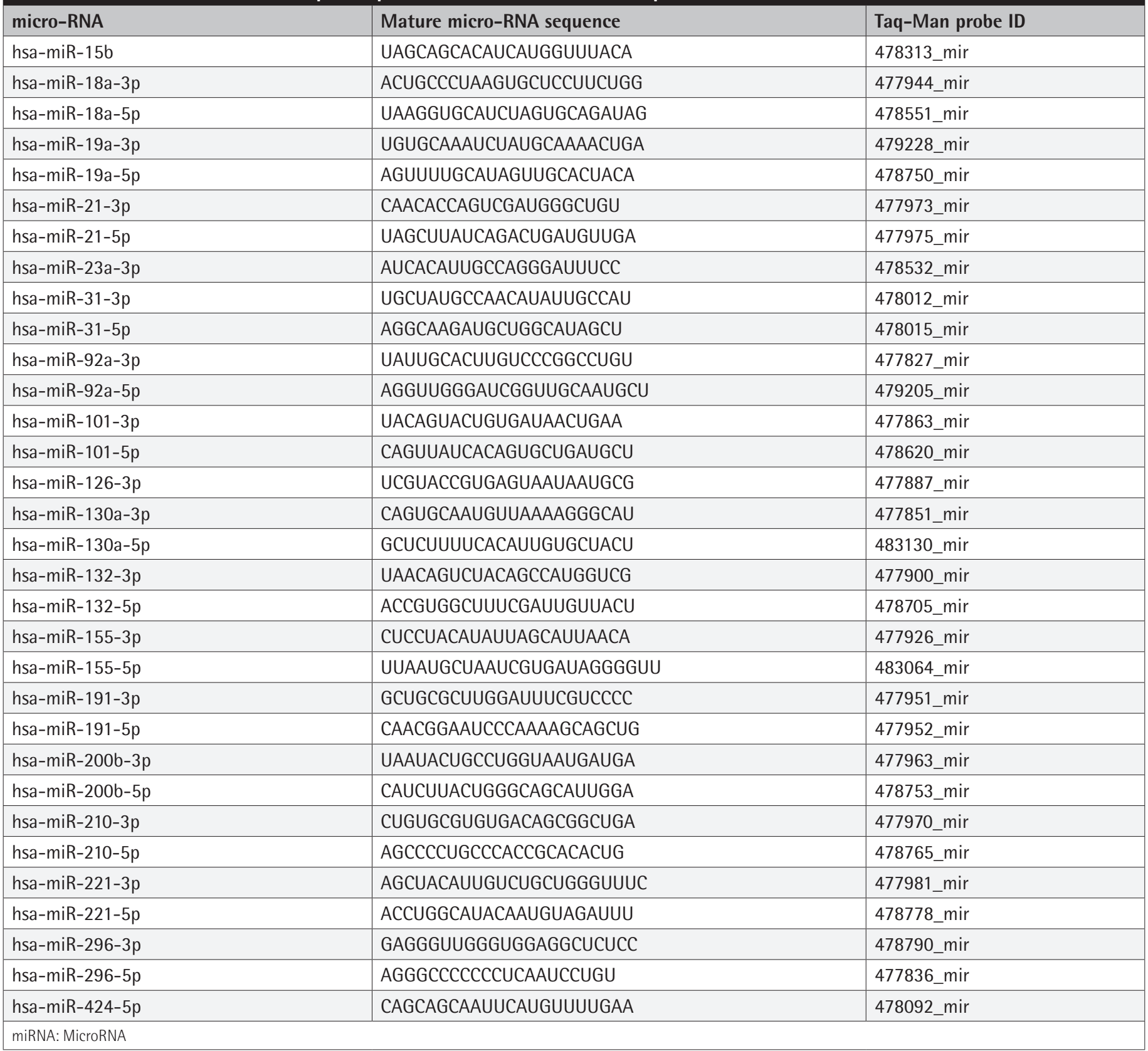


in recent years. Xia et al. ${ }^{20}$ suggested that miR_15b played a role as a tumor inhibitory agent in cell cycle regulation in glioblastomas. In another study, increased miR_15b expression was reported in analyses performed in serum and cerebrospinal fluid of patients ${ }^{21,22}$. Finally, Chen et al. ${ }^{23}$ reported that miR_15b showed its effect on gliomagenesis through sal-like protein
4. In our study, increased expression values of miR_15b were detected and it was thought to play an important role in the molecular process.

The miR_17-92 family is a polycistronic miR family that is involved in the coding of more than one protein and has

Table 2. Relative miR expression levels determined in GBM tumor spheres in the groups administered 200 nM ruxolitinib, compared to the control groups without treatment, and the results of the related statistical analysis

\begin{tabular}{|c|c|c|c|c|c|}
\hline \multirow{2}{*}{ miRNA } & \multirow[b]{2}{*}{ Mean value } & \multirow[b]{2}{*}{ Standard deviation } & \multirow[b]{2}{*}{$p$ value } & \multicolumn{2}{|l|}{$95 \% \mathrm{Cl}$} \\
\hline & & & & Decrease & Increase \\
\hline \multicolumn{6}{|c|}{ MiRs with significantly increased expression } \\
\hline miR_18a_5p & 154.640 & 18.073 & 0.000 & -218.814 & -87.006 \\
\hline miR_19a_3p & 44.298 & 4.543 & 0.000 & -59.818 & -26.688 \\
\hline miR_31_3p & 226.034 & 46.217 & 0.012 & -391.855 & -54.810 \\
\hline miR_130a_5p & 4.144 & 0.802 & 0.046 & -5.920 & -0.064 \\
\hline miR_132_3p & 1.824 & 0.135 & 0.002 & -1.316 & -0.325 \\
\hline miR_155_3p & 2.657 & 0.418 & 0.038 & -3.204 & -0.101 \\
\hline miR_210_3p & 0.546 & 0.103 & 0.019 & 0.097 & 0.974 \\
\hline miR_221_3p & 0.619 & 0.060 & 0.003 & 0.159 & 0.673 \\
\hline miR_424_5p & 0.537 & 0.129 & 0.036 & 0.053 & 1.393 \\
\hline \multicolumn{6}{|c|}{ miRs without significant change } \\
\hline miR_18a_3p & 1.508 & 0.351 & 0.984 & -1.501 & 1.472 \\
\hline miR_19a_5p & 3.132 & 0.934 & 0.232 & -5.443 & 1.390 \\
\hline miR_23a_3p & 0.627 & 0.125 & 0.074 & -0.049 & 0.996 \\
\hline miR_27a_3p & 0.667 & 0.114 & 0.109 & -0.081 & 0.757 \\
\hline miR_31_5p & 1.038 & 0.087 & 0.932 & -0.346 & 0.376 \\
\hline miR_126_3p & 0.881 & 0.081 & 0.335 & -0.174 & 0.490 \\
\hline miR_132_5p & 13.145 & 7.780 & 0.384 & -40.506 & 16.229 \\
\hline miR_155_5p & 3.413 & 1.562 & 0.663 & -7.154 & 4.641 \\
\hline miR_191_3p & 1.190 & 0.603 & 0.861 & -2.389 & 2.012 \\
\hline miR_191_5p & 0.873 & 0.074 & 0.229 & -0.146 & 0.580 \\
\hline miR_200b_3p & 2.555 & 0.799 & 0.295 & -4.428 & 1.408 \\
\hline miR_210_5p & 0.728 & 0.113 & 0.159 & -0.128 & 0.735 \\
\hline miR_221_5p & 2.629 & 1.243 & 0.823 & -5.289 & 4.247 \\
\hline miR_296_3p & 1.054 & 0.218 & 0.958 & -0.802 & 0.845 \\
\hline miR_296_5p & 1.843 & 0.281 & 0.278 & -1.717 & 0.518 \\
\hline
\end{tabular}


6 members $^{24}$. In our study, we detected an increase in the expression values of miR_18a and miR_19a in this family (Table 2). It has been reported that the expression of mir_18a is increased in human prostate, breast and colorectal cancers, especially with its close relationship with apoptosis ${ }^{19,25}$. They reported a correlation between the increased tumor grade of
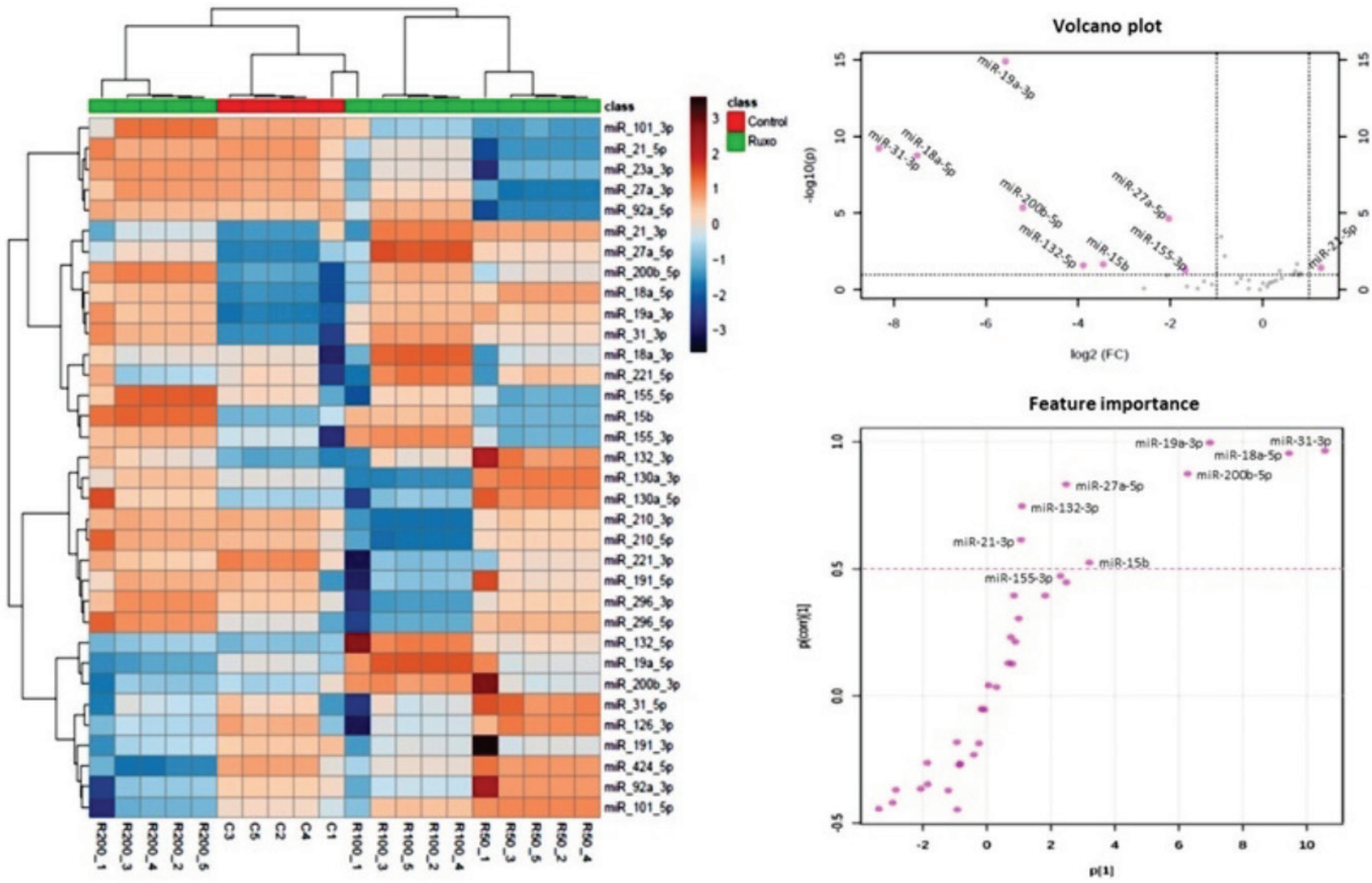

Figure 2. a) Heatmap analysis using normalized miR expression values (distance measurement parameter: euclidian, cluster algorithm: ward), b) The most important miRNAs selected with fold change threshold (x) 2 in Volcano plot analysis and t-test significance level threshold $(y)$ 0.1. The red dashed line shows miRs significantly above the threshold (both fold increase and $p$ values were undergone logarithmic transformation), c) S-graph combining covariance correlation [p (corr)] loading profile, showing variable significance obtained by OPLS-Discriminant analysis. All biomarker analyses were performed between $200 \mathrm{nM}$ ruxolitinibtreated and untreated control groups

miRNA: MicroRNA

Table 3. The most important features of miRs determined by Volcano plot and Discriminant Analysis of Orthogonal-Orthogonal Projections to Latent Structures

\begin{tabular}{|l|l|l|l|l|l|l|}
\hline \multicolumn{4}{|l}{ Volcano plot } \\
\hline miRNA & FC & log2(FC) & p value & -log10(p) & Important feature \\
\hline miR_15b & 0.0910 & -34.5750 & 0.0216 & 16.6640 & 320.8360 & 0.5251 \\
\hline miR_18a_5p & 0.0056 & -74.8870 & $1.74 E-05$ & 87.5930 & 944.6110 & 0.9546 \\
\hline miR_19a_3p & 0.0209 & -55.7790 & $1.31 E-11$ & 14.8820 & 69.7660 & 0.9965 \\
\hline miR_21_5p & 23.9670 & 12.6110 & 0.0372 & 14.2940 & 106.7570 & 0.6144 \\
\hline miR_27a_5p & 0.2433 & -20.3910 & $2.27 E-02$ & 46.4320 & 247.7050 & 0.8329 \\
\hline miR_31_3p & 0.0031 & -83.1770 & $5.95 E-06$ & 92.2570 & 105.6860 & 0.9647 \\
\hline miR_132_5p & 0.0674 & -38.9060 & 0.0253 & 15.9630 & 109.7980 & 0.7473 \\
\hline miR_155_3p & 0.3118 & -16.8130 & 0.0528 & 1.2770 & 230.0530 & 0.4726 \\
\hline miR_200b_5p & 0.0272 & $4.46 E-03$ & 53.5050 & 628.0550 & 0.8749 \\
\hline FC: Fold change, log: Logarithm, corr: Correlation, $p$ : Significance level & & & \\
\hline
\end{tabular}


glioblastomas and increased miR_18a expression values ${ }^{26,27}$. On the other hand, Jiang et al. ${ }^{28}$ targeted miR_18a as responsible for the low expression values of the receptor-related orphan receptor A (RORA) protein, which they associated with a good prognosis, in high-grade glioblastomas. It has been suggested that the other member of the family, miR_19a, is expressed in many types of cancer and can be used as a biomarker of cancer progression ${ }^{29}$. Phosphatase and tensin homolog (PTEN) is a well-known tumor suppressor gene and is the target protein of miR_19a. It has been reported that with the inhibition of miR_19a, the activation of PTEN is increased and the invasion of glioma cells is prevented in this way ${ }^{30}$. In the study of Malzkorn et al. ${ }^{31}$, they reported that there was an increase in miR_19a expression values in tissues obtained from people with a diagnosis of glioblastoma, and that miR_19a inhibition prevented cell proliferation of glioblastoma cells. In the present study, a statistically significant increase was detected in the expression values of miR_19a (Figure 3). These results suggest that the effect of ruxolitinib on tumor invasion may be related to $m i R \_19 a$ rather than miR_18a.

miR_31 is a miR known for its anti-cancer properties for many types of cancer, but also reported to inhibit metastasis in breast cancer ${ }^{32,33}$. Its oncogenic properties have been reported in lung and colon cancers ${ }^{34,35}$. Its decreased expression has been reported in glioblastomas compared to normal brain tissue $^{36}$. The target protein of miR_31 is radixin ${ }^{30}$. Radixin is a member of the ezrin/radixin/moesin protein family, which is responsible for binding between the cell membrane and the cytoskeleton ${ }^{37}$. Wang et al. ${ }^{38}$ reported that decreased miR_31a and high radixin expression were associated with poor Karnofsky performance and poor survival in patients with glioblastoma. In another study, it was reported that miR_31 inhibits nuclear factor-kappa B signaling, which is known to be highly effective in glioblastomas ${ }^{39}$. In our study, increased expression of miR_31a was detected with ruxolitinib administration (Table 2). This increased expression was also found to correlate with inhibition of invasion (Figure 3). Ruxolitinib is a janus kinase (JAK) inhibitor. It is thought that the target protein of miR_31, radixin, is also included in the structure of JAK ${ }^{40}$. These data suggest that there is a molecular link between JAK/STAT signaling and miR_31 in the invasion inhibitory effect of ruxolitinib, but this needs to be confirmed by further studies.

miR_155 is a well-known oncogenic miR with 147 target genes identified in the literature. The presence of many target genes is met with increasing interest in their clinical significance ${ }^{41}$. Elevated expression values have been reported in many types of cancer, including glioblastoma, lung cancer, breast cancer, Burkitt's lymphoma, and leukemia ${ }^{41-43}$. In the study by D'Urso et al. ${ }^{44}$, they found an increase in the expression of miR_155 in both primary and secondary glioblastoma patients and suggested that it showed its oncogenic effect in glioblastomas through the target gene of miR_155, $\gamma$-aminobutyric acid A receptor 1 (GABRA 1$)^{44}$. GABRA 1 is the receptor for gamma acetyl amunobutyric acid (GABA), whose role in brain functions is well known. GABA is one of the main inhibitory neurotransmitters in the human brain. With its increased expression, it is known to increase tumor cell proliferation in glioblastomas ${ }^{45}$. In the present study, increased miR_155 expression was detected in U87

\section{a}

\begin{tabular}{|c|c|c|c|}
\hline Variable & & Tumour volume & Invasion rate \\
\hline 1. Tumour volume & $\begin{array}{l}\text { Pearson's r } \\
\text { D-value }\end{array}$ & $\underline{-}$ & \\
\hline 2. Invasion rate & $\begin{array}{l}\text { Pearson's r } \\
\text { D-value }\end{array}$ & $\begin{array}{l}0.707 \cdots \\
<.001\end{array}$ & $\underline{-}$ \\
\hline 3. $m i R \_15 b$ & $\begin{array}{l}\text { Pearson's t } \\
\text { p-value }\end{array}$ & $\begin{array}{l}-0.659 * * \\
0.002\end{array}$ & $\begin{array}{l}-0.861 \cdots \\
<.001\end{array}$ \\
\hline 4. miR_18a_5p & $\begin{array}{l}\text { Pearson's r } \\
\text { p-value }\end{array}$ & $\begin{array}{c}-0.543^{\circ} \\
0.013\end{array}$ & $\begin{array}{r}-0.357 \\
0.123\end{array}$ \\
\hline 5. miR_19a_3p & $\begin{array}{l}\text { Pearson's r } \\
\text { p-value }\end{array}$ & $\begin{array}{l}-0.713^{\cdots} \\
<.001\end{array}$ & $\begin{array}{c}-0.455^{\circ} \\
0.044\end{array}$ \\
\hline 6. miR_21_5p & $\begin{array}{l}\text { Pearson's r } \\
\text { D-value }\end{array}$ & $\begin{array}{l}0.138 \\
0.561\end{array}$ & $\begin{array}{r}-0.079 \\
0.741\end{array}$ \\
\hline 7. mir_27a_5p & $\begin{array}{l}\text { Pearson's I } \\
\text { D-value }\end{array}$ & $\begin{array}{r}-0.413 \\
0.070\end{array}$ & $\begin{array}{r}-0.136 \\
0.567\end{array}$ \\
\hline 8. miR_31_30 & $\begin{array}{l}\text { Pearson'st } \\
\text { D-value }\end{array}$ & $\begin{array}{c}-0.461 . \\
0.041\end{array}$ & $\begin{array}{r}-0.533^{\circ} \\
0.015\end{array}$ \\
\hline 9. miR_132_5p & $\begin{array}{l}\text { Pearson's I } \\
\text { p-value }\end{array}$ & $\begin{array}{r}-0.144 \\
0.544\end{array}$ & $\begin{array}{r}-0.058 \\
0.807\end{array}$ \\
\hline 10. miR_155_3D & $\begin{array}{l}\text { Pearson's t } \\
\text { p-value }\end{array}$ & $\begin{array}{l}-0.572 * \\
0.008\end{array}$ & $\begin{array}{l}-0.625 * \\
0.003\end{array}$ \\
\hline 11. miR_200b_5p & $\begin{array}{l}\text { Pearson's r } \\
\text { p-value }\end{array}$ & $\begin{array}{l}-0.673^{*} \\
0.001\end{array}$ & $\begin{array}{l}-0.957 \cdots \\
<.001\end{array}$ \\
\hline
\end{tabular}

b
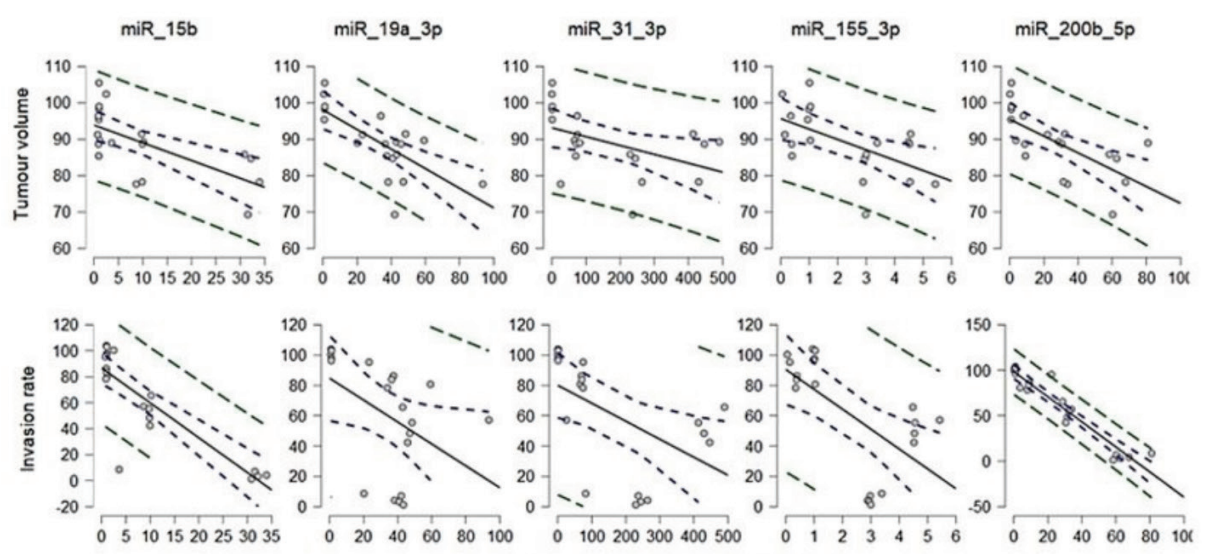

miRNA expressions (Relative fold change)

Figure 3. Tumor size, invasion rate, and the most significant angio-miR expression relationship a) Correlation matrix generated according to the Pearson correlation coefficient b) Scattered points, 95\% confidence interval (blue line) and 95\% predictive interval (green line) 
invasion, which was strongly inhibited by ruxolitinib. This result suggests that ruxolitinib does not exert its inhibitory invasion effect on miR_155, which is known for its oncogenic effect.

miR_200b is a member of the miR_200 family and has been reported to be involved in many types of cancer, including glioblastomas ${ }^{46}$. It has been reported to inhibit tumor growth in malignant glioblastoma cell lines and human tissues with low expression values in cell lines ${ }^{47}$. It has been reported that it exerts its inhibitory effect on glioblastomas through its target gene, element-binding protein $1(C R E B 1)^{47}$. Liu et al. ${ }^{48}$ associated decreased expression of miR_200b with poor prognosis, and they suggested that this effect occurred on another target gene of miR_200b, $R A B$ gene family ${ }^{48}$. Chang et al. ${ }^{49}$ have reported that increased expression of RAB3C, a member of the RAN family, is associated with high grade and poor prognosis in colorectal cancers, and that the expression of this gene decreases with ruxolitinib administration and prevents cancer cell movement. In our study, a strong correlation was found between U87 cell growth and invasion, which was significantly inhibited by ruxolitinib, in miR_200b expression. Considering the close relationship of ruxolitinib with the RAB family, which is the target gene of this miR, we think that miR_200b may be closely related to the effect of ruxolitinib.

\section{Study Limitations}

Although the presented study reveals results that we think are important, it has some limitations. The most important limitation is that the study is an in vitro study. In addition, the validation of the obtained data through human tumor tissues can make the results even more reliable. Similarly, investigation of changes in protein expression along with changes in gene expression may contribute to the elucidation of the molecular mechanism more. In addition, we think that our data reflect some important potential clinical scenarios for ruxolitinibangio-miR association in GBM patients.

\section{CONCLUSION}

We demonstrated that GBM growth and invasion modeled in tumor spheroids was significantly inhibited specifically by $200 \mathrm{nM}$ ruxolitinib treatment. We also identified a strong interaction between ruxolitinib and angio-miRs in the ruxolitinib-treated groups. Our results revealed that miR_15b, miR_19a, miR_31_3p, miR_155_3p and miR_200b among 34 angio-miRs that we investigated were statistically significantly changed by ruxolitinib treatment, and all of them were associated with tumor growth and invasion. Our results suggest that ruxolitinib is an effective anti-tumor therapeutic in glioblastoma tumor spheroids, possibly by altering the expression profile of angio-miRs and thereby inhibiting angiogenesis-related signals. However, it is thought that more studies are needed to validate the data of our study and make it clinically usable.

\section{Ethics}

Ethics Committee Approval: Commercial cells were used in our study. Ethics committee approval is not required for such studies.

Informed Consent: There is no need.

Peer-review: Externally and internally peer-reviewed.

\section{Authorship Contributions}

Surgical and Medical Practices: E.D., O.D., Concept: E.D., O.D., Design: E.D., O.D., Data Collection or Processing: E.D., O.D., Analysis or Interpretation: E.D., O.D., Literature Search: E.D., O.D., Writing: E.D., O.D.

Conflict of Interest: No conflict of interest was declared by the authors.

Financial Disclosure: The authors declared that this study received no financial support.

\section{REFERENCES}

1. Salinas-Vera YM, Marchat LA, Gallardo-Rincón D, Ruiz-García E, AstudilloDe La Vega $H$, Echavarria-Zepeda R, et al. AngiomiRs: MicroRNAs driving angiogenesis in cancer (Review). Int J Mol Med. 2019;43:657-70.

2. Pang C, Guan $Y$, Zhao K, Chen L, Bao Y, Cui R, et al. Up-regulation of microRNA-15b correlates with unfavorable prognosis and malignant progression of human glioma. Int J Clin Exp Pathol. 2015;8:4943-52.

3. Gabriely G, Wurdinger T, Kesari S, Esau CC, Burchard J, Linsley PS, et al. MicroRNA 21 promotes glioma invasion by targeting matrix metalloproteinase regulators. Mol Cell Biol. 2008;28:5369-80.

4. Anindo $\mathrm{MI}$, Yaqinuddin A. Insights into the potential use of microRNAs as biomarker in cancer. Int J Surg. 2012;10:443-9.

5. Cuddapah VA, Robel S, Watkins S, Sontheimer H. A neurocentric perspective on glioma invasion. Nat Rev Neurosci. 2014;15:455-65.

6. Jain RK, di Tomaso E, Duda DG, Loeffler JS, Sorensen AG, Batchelor $\Pi$. Angiogenesis in brain tumours. Nat Rev Neurosci. 2007;8:610-22.

7. Price SJ, Gillard JH. Imaging biomarkers of brain tumour margin and tumour invasion. Br J Radiol. 2011;84(Spec No 2):S159-67.

8. Batchelor $\Pi$, Reardon DA, de Groot JF, Wick W, Weller M. Antiangiogenic therapy for glioblastoma: current status and future prospects. Clin Cancer Res. 2014;20:5612-9.

9. Beyer S, Fleming J, Meng W, Singh R, Haque SJ, Chakravarti A. The Role of miRNAs in Angiogenesis, Invasion and Metabolism and Their Therapeutic Implications in Gliomas. Cancers (Basel). 2017;9:85.

10. Delen E, Doğanlar O. The Dose Dependent Effects of Ruxolitinib on the Invasion and Tumorigenesis in Gliomas Cells via Inhibition of Interferon Gamma-Depended JAK/STAT Signaling Pathway. J Korean Neurosurg Soc. 2020;63:444-54

11. Delen E, Doganlar O, Doganlar ZB, Delen 0. Inhibition of the Invasion of Human Glioblastoma U87 Cell Line by Ruxolitinib: A Molecular Player of miR-17 and miR-20a Regulating JAK/STAT Pathway. Turk Neurosurg. 2020;30:182-9.

12. Serocki M, Bartoszewska $S$, Janaszak-Jasiecka A, Ochocka RJ, Collawn JF, Bartoszewski R. miRNAs regulate the HIF switch during hypoxia: a novel therapeutic target. Angiogenesis. 2018;21:183-202. 
13. Caporali A, Emanueli C. MicroRNA regulation in angiogenesis. Vascul Pharmacol. 2011;55:79-86.

14. Berthois $Y$, Delfino $C$, Metellus $P$, Fina $F$, Nanni-Metellus $I$, Al Aswy $H$, et al. Differential expression of miR200a-3p and miR21 in grade II-III and grade IV gliomas: evidence that miR200a-3p is regulated by $0^{6}$-methylguanine methyltransferase and promotes temozolomide responsiveness. Cancer Biol Ther. 2014;15:938-50.

15. Barbano R, Palumbo O, Pasculli B, Galasso M, Volinia S, D'Angelo V, et al. A miRNA signature for defining aggressive phenotype and prognosis in gliomas. PLoS One. 2014;9:e108950.

16. Livak KJ, Schmittgen TD. Analysis of relative gene expression data using real-time quantitative PCR and the 2(-Delta Delta C(T)) Method. Methods. 2001;25:402-8.

17. Ma L, Teruya-Feldstein J, Weinberg RA. Tumour invasion and metastasis initiated by microRNA-10b in breast cancer. Nature. 2007;449:682-8.

18. Iseki $Y$, Shibutani M, Maeda K, Nagahara H, Fukuoka T, Matsutani $S$, et al. MicroRNA-96 Promotes Tumor Invasion in Colorectal Cancer via RECK. Anticancer Res. 2018;38:2031-5.

19. Fang $L L$, Wang $X H$, Sun $B F$, Zhang $X D$, Zhu $X H$, Yu ZJ, et al. Expression, regulation and mechanism of action of the miR-17-92 cluster in tumor cells (Review). Int J Mol Med. 2017;40:1624-30.

20. Xia H, Qi Y, Ng SS, Chen $X$, Chen $S$, Fang $M$, et al. MicroRNA-15b regulates cell cycle progression by targeting cyclins in glioma cells. Biochem Biophys Res Commun. 2009;380:205-10.

21. Ivo D'Urso P, Fernando D'Urso O, Damiano Gianfreda C, Mezzolla V, Storelli C, Marsigliante S. miR-15b and miR-21 as Circulating Biomarkers for Diagnosis of Glioma. Curr Genomics. 2015;16:304-11.

22. Baraniskin A, Kuhnhenn J, Schlegel U, Maghnouj A, Zöllner H, Schmiegel W, et al. Identification of microRNAs in the cerebrospinal fluid as biomarker for the diagnosis of glioma. Neuro Oncol. 2012;14:29-33.

23. Chen LP, Zhang NN, Ren XQ, He J, Li Y. miR-103/miR-195/miR-15b Regulate SALL4 and Inhibit Proliferation and Migration in Glioma. Molecules. 2018;23:2938.

24. Chen L, Li C, Zhang R, Gao X, Qu X, Zhao M, et al. miR-17-92 cluster microRNAs confers tumorigenicity in multiple myeloma. Cancer Lett. 2011;309:62-70.

25. Hsu TI, Hsu CH, Lee KH, Lin JT, Chen CS, Chang KC, et al. MicroRNA$18 \mathrm{a}$ is elevated in prostate cancer and promotes tumorigenesis through suppressing STK4 in vitro and in vivo. Oncogenesis. 2014;3:e99.

26. Wu W, Zhou X, Yu T, Bao Z, Zhi T, Jiang K, et al. The malignancy of miR18a in human glioblastoma via directly targeting CBX7. Am J Cancer Res. 2017;7:64-76.

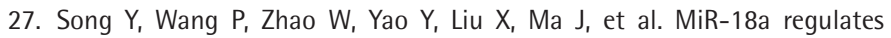
the proliferation, migration and invasion of human glioblastoma cell by targeting neogenin. Exp Cell Res. 2014;324:54-64.

28. Jiang Y, Zhou J, Zhao J, Hou D, Zhang H, Li L, et al. MiR-18a-downregulated RORA inhibits the proliferation and tumorigenesis of glioma using the TNF$\alpha$-mediated NF-кB signaling pathway. EBioMedicine. 2020;52:102651.

29. Peng $Y$, Huang $D, M a ~ K$, Deng $X$, Shao Z. MiR-19a as a prognostic indicator for cancer patients: a meta-analysis. Biosci Rep. 2019;39:BSR20182370.

30. Balachandran AA, Larcher LM, Chen S, Veedu RN. Therapeutically Significant MicroRNAs in Primary and Metastatic Brain Malignancies. Cancers (Basel). 2020;12:2534.

31. Malzkorn B, Wolter M, Liesenberg F, Grzendowski M, Stühler K, Meyer HE, et al. Identification and functional characterization of microRNAs involved in the malignant progression of gliomas. Brain Pathol. 2010;20:539-50.

32. Valastyan $S$, Reinhardt F, Benaich $N$, Calogrias D, Szász AM, Wang ZC,e $t$ al . A pleiotropically acting microRNA, miR-31, inhibits breast cancer metastasis. Cell. 2009;137:1032-46.
33. Luo L, Yang F, Ding JJ, Yan DL, Wang DD, Yang SJ, et al. MiR-31 inhibits migration and invasion by targeting SATB2 in triple negative breast cancer. Gene. 2016;594:47-58.

34. Liu $X$, Sempere LF, Ouyang $H$, Memoli VA, Andrew AS, Luo $Y$, et al. MicroRNA-31 functions as an oncogenic microRNA in mouse and human lung cancer cells by repressing specific tumor suppressors. J Clin Invest. 2010;120:1298-309.

35. Cottonham CL, Kaneko $\mathrm{S}, \mathrm{Xu}$ L. miR-21 and miR-31 converge on TIAM1 to regulate migration and invasion of colon carcinoma cells. J Biol Chem. 2010;285:35293-302.

36. Hua D, Ding D, Han X, Zhang W, Zhao N, Foltz G, et al. uman miR-31 targets radixin and inhibits migration and invasion of glioma cells. Oncol Rep. 2012;27:700-6.

37. Sato N, Funayama N, Nagafuchi A, Yonemura S, Tsukita S, Tsukita S. A gene family consisting of ezrin, radixin and moesin. Its specific localization at actin filament/plasma membrane association sites. J Cell Sci. 1992;103:13143.

38. Wang S, Jiao B, Geng S, Song J, Liang Z, Lu S. Concomitant microRNA-31 downregulation and radixin upregulation predicts advanced tumor progression and unfavorable prognosis in patients with gliomas. J Neurol Sci. 2014;338:71-6.

39. Rajbhandari R, McFarland BC, Patel A, Gerigk M, Gray GK, Fehling SC, et al. Loss of tumor suppressive microRNA-31 enhances TRADD/NF-kB signaling in glioblastoma. Oncotarget. 2015;6:17805-16.

40. Haan S, Margue C, Engrand A, Rolvering C, Schmitz-Van de Leur H, Heinrich PC, et al. Dual role of the Jak1 FERM and kinase domains in cytokine receptor binding and in stimulation-dependent Jak activation. J Immunol. 2008;180:998-1007.

41. Mattiske S, Suetani RJ, Neilsen PM, Callen DF. The oncogenic role of miR155 in breast cancer. Cancer Epidemiol Biomarkers Prev. 2012;21:1236-43.

42. Babar IA, Cheng $C J$, Booth $C J$, Liang $X$, Weidhaas JB, Saltzman WM, et al. Nanoparticle-based therapy in an in vivo microRNA-155 (miR155)-dependent mouse model of Iymphoma. Proc Natl Acad Sci U S A. 2012;109:E1695-704.

43. Mallardo M, Poltronieri P, D'Urso OF. Non-protein coding RNA biomarkers and differential expression in cancers: a review. J Exp Clin Cancer Res. 2008;27:19.

44. D'Urso PI, D'Urso OF, Storelli C, Mallardo M, Gianfreda CD, Montinaro A, et al. miR-155 is up-regulated in primary and secondary glioblastoma and promotes tumour growth by inhibiting GABA receptors. Int J Oncol. 2012;41:228-34.

45. Jung $E$, Alfonso J, Osswald M, Monyer $H$, Wick W, Winkler F. Emerging intersections between neuroscience and glioma biology. Nat Neurosci. 2019;22:1951-60.

46. Men D, Liang $Y$, Chen L. Decreased expression of microRNA-200b is an independent unfavorable prognostic factor for glioma patients. Cancer Epidemiol. 2014;38:152-6.

47. Peng B, Hu S, Jun Q, Luo D, Zhang X, Zhao H, et al. MicroRNA-200b targets CREB1 and suppresses cell growth in human malignant glioma. Mol Cell Biochem. 2013;379:51-8.

48. Liu Q, Tang H, Liu X, Liao Y, Li H, Zhao Z, et al. miR-200b as a prognostic factor targets multiple members of RAB family in glioma. Med Oncol. 2014;31:859.

49. Chang YC, Su CY, Chen MH, Chen WS, Chen CL, Hsiao M. Secretory RAB GTPase 3C modulates IL6-STAT3 pathway to promote colon cancer metastasis and is associated with poor prognosis. Mol Cancer. 2017;16:135. 